\title{
Mentoring for future female engineers: pilot at the Higher Polytechnic School of Zamora
}

\author{
Ana-Belén González-Rogado \\ Dept. of Computer Science and \\ Automation \\ University of Salamanca \\ Zamora, Spain \\ 0000-0002-7859-8730
}

\author{
Alicia García-Holgado \\ Dept. of Computer Science and \\ Automation \\ University of Salamanca \\ Salamanca, Spain \\ 0000-0001-9663-1103
}

\author{
Francisco J. García-Peñalvo \\ Dept. of Computer Science and \\ Automation \\ University of Salamanca \\ Salamanca, Spain \\ 0000-0001-9987-5584
}

\begin{abstract}
The gender gap is a problem that affects all areas and regions in the world. The lack of females depends on different external and internal factors that make it a complex problem. In particular, this gap is most pronounced in engineering. Engineering and technical studies have a shortage of female vocations and a high dropout rate. In this paper, we present the pilot peer-mentoring programme, which has been carried out in the 2020-21 academic year at the University of Salamanca in the Higher Polytechnic School of Zamora. Mentoring has been given to first-year female students of engineering degrees. The implementation of the pilot programme has provided helpful information for implementing the mentoring programme from the 2021-22 academic year.
\end{abstract}

Keywords- gender gap, peer mentoring, engineering education, higher education, virtual campus.

\section{INTRODUCTION}

The dropout rate at Spanish universities is higher in technical studies than in other branches of knowledge. In oncampus undergraduate studies in the field of Engineering and Architecture, this rate is $36 \%$ [1]. When students do not complete their studies, we are wasting resources. The cost of dropout in Spanish universities represents $11.9 \%$ of annual university expenditure [1].

We cannot forget the gender gap. According to a study in 110 countries, STEM careers are chosen by only $30 \%$ of women [2]. These figures vary from one country to another and from one institution to another.

When starting university studies, these students may feel lost or lonely, facing new spaces, new educational methodologies [3, 4], and sometimes stereotypes related to engineering. Most dropouts occur in the first year of university [1], a critical moment. Monitoring and accompanying them in this first year increases the chances of success [5].

Mentoring can be defined as "A process of continuous feedback of help and guidance between the mentor (a senior student who has the knowledge and skills to help), and a student or a group of incoming students, in order to alleviate their needs and optimise their development and learning potential" [6]

Peer learning is a compelling and effective method [7]. It can be helpful in the first year of students' entry to university. When mentoring is applied through peer learning, it provides benefits for those who mentor, those who are mentored, and the university itself [6]. The university benefits in several areas: organisational, quality, increased student satisfaction and lower dropout rates. The mentor-student develops new skills, increases self-esteem and satisfaction. The mentee is the greatest beneficiary; they receive clarification and guidance in the academic, professional or personal field at a critical moment in their training.

In the academic year 2020-21, a "Peer Mentoring Pilot Programme" has been carried out in the Higher Polytechnic School of Zamora (EPSZ, Escuela Politécnica de Zamora) at the University of Salamanca (Spain). The programme has been coordinated by the GRoup of Interaction And e-Learning (GRIAL) [8]. It is being developed in association with the project "Building the future of Latin America: engaging women into STEM" (W-STEM) funded within the framework of the Erasmus+ Programme, Capacity-building in Higher Education of the European Union [9]. Among its objectives, the project has implemented strategies and organisational mechanisms in university policies to improve attraction, access and orientation at the university level in STEM (Science, Technology, Engineering and Mathematics) programmes.

The Higher Polytechnic School of Zamora is a centre of the University of Salamanca (USAL) located on the Viriato Campus in Zamora. Six bachelor's degrees and two double degrees in Engineering and Architecture are taught at this centre:

- Degree in Technical Architecture (GAT).

- Degree in Agri-Food Engineering (GIA).

- Degree in Civil Engineering (GIC).

- Degree in Mechanical Engineering (GIM).

- Degree in Computer Engineering in Information Systems (GIISI).

- Degree in Materials Engineering (GIMAT).

- Double Degree in Materials Engineering and Mechanical Engineering (GIMM).

- Double Degree in Computer Engineering in Information Systems and Information and Documentation (GIID).

The number of students has decreased in the last decade, as has happened in Spain in many technical degrees. The decrease in the presence of women in these degrees is significant. $38 \%$ of USAL students are men and $62 \%$ are women (the academic year 2019-20). However, when analysing the engineering studies taught at the EPSZ, the data are quite different. Women represent on average $23 \%$ of the student body (the academic year 2019-20), ranging from $15 \%$ in the GIM to $39 \%$ in the GAT (Figure 1). The presence of 
international students has also increased in recent years, mainly from Morocco and, to a lesser extent, from China.

It is essential to attract students to EPSZ and to balance the presence of men and women in technical studies. As well as minimising dropout rates. Ensure that the majority of those who start their university studies at EPSZ complete them.

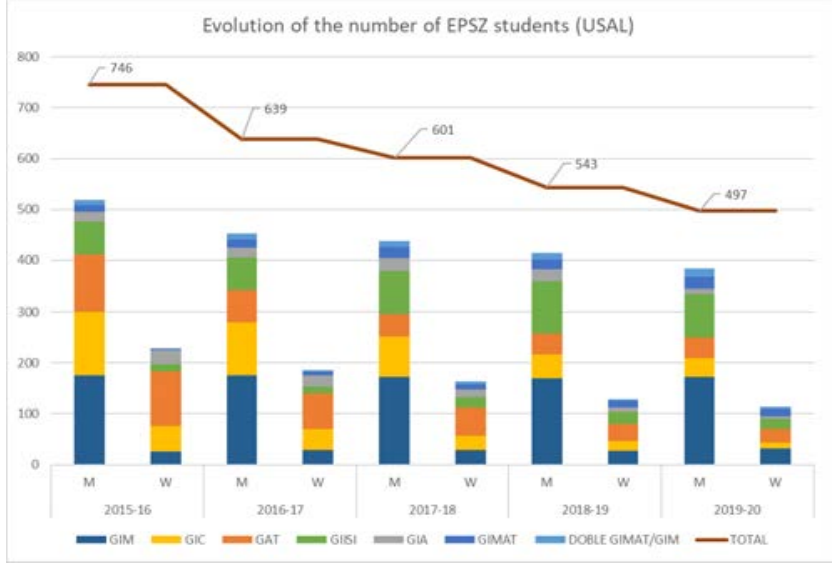

Fig. 1 Evolution of EPSZ student, degrees and gender. Source:

https://indicadores.usal.es/portal/estudiantes/evolucion-dematricula/evolucion-de-la-matricula-de-grado/

We propose this pilot programme as a first phase to the one we intend to carry out from the 2021-22 academic year in coordination with other universities participating in the WSTEM project.

\section{PEOPLE}

The mentoring model implemented uses a three-way relationship $[8,10]$. It involves a mentor teacher, the peermentor and the mentee.

The aim of the mentoring was to guide and support firstyear female students socially, administratively and academically $[8,11]$ :

- Social orientation: Orientation to successfully adapt to university life.

- Administrative guidance: Guidance on administrative procedures and knowledge of EPSZ structures.

- Academic guidance: Guidance for successfully tackling subjects in the first year; orientation for enrolment in the following year.

It was carried out in the second semester of the 2020-21 academic year (February to June). One or two first-year students, one or two third or fourth-year students and one tutor per degree programme took part (Table 1).

Table 1 Summary data. Mentoring Pilot Programme 2020-21

\begin{tabular}{|l|c|}
\hline & Number \\
\hline EPSZ degrees & 6 \\
\hline Mentored students & 7 \\
\hline Mentor students & 8 \\
\hline Mentor teachers & 6 \\
\hline Coordinating teachers & 2 \\
\hline
\end{tabular}

\section{A. Tutorial teaching staff}

The faculty mentors are teaching staff with teaching experience in the degree programme of the mentor students.
Their role is to supervise and monitor the peer mentoring process. They will act as support for the mentor student.

The following contents were considered for the training of the mentor teaching staff:

- Guidance and tutorial action plan, co-education.

- Uncertainty in the classroom.

- Emotional intelligence.

- Gender perspective, inclusive language, sensitisation, soft skills.

Finally, teacher training in this pilot project was limited to particular topics. As this was a pilot project, teachers who regularly participate in teacher training and improvement courses were sought.

For the pilot project, we had a group of six teachers who are used to working in multidisciplinary teams. The participating teachers have extensive experience in research and teaching innovation. They have been working together since the 2004-05 academic year on teaching innovation and improvement projects.

\section{B. Mentor students}

The mentor students are male or female students in the upper years of the degrees offered at the EPSZ. The basis of the programme is the shared experience and the relationship between equals. Two people with similar experiences and no power relationship between them can help each other more effectively.

Although the mentees will be the primary beneficiaries of the process, the mentor students also benefit from the process. According to [11], they improve their decision-making, leadership, planning and communication skills and increase their commitment to the university and the other participants in the activity. In addition, they develop technical (knowledge), social, participation (knowing how to be) and methodological (knowing how to do) competences [12].

The training of mentor students should focus on the development of:

- Technical competences: profile of incoming students; understanding of the mentoring process.

- Methodological competences: identification of the needs of incoming students; communication, organisation and work planning techniques; problemsolving procedures.

- Personal competences: respect for the mentor's principles of action; empowerment; inclusive language; awareness-raising; soft skills.

The EPSZ student delegation was asked to collaborate in the pilot programme. In the academic year 2020-21, the student delegation is composed of 14 students $(8$ women and 6 men) with a female president. Eight of them participated (6 women and 2 men).

Each mentor student was assigned one or two first-year students as mentees. Their work focused on providing guidance and counselling to the mentees to assist informally in the academic and social integration of the first-year students in EPSZ. 
The members of the student delegation get to know the school. Its structures and functioning. Therefore, the training focused on other areas. Audiovisual pills were created or compiled on topics that would help them in their mentoring process: understanding the process; identifying the new students needs; inclusive language; awareness-raising and soft skills.

\section{Mentored female students}

The mentees profile sought was female students who had started their studies at EPSZ in the academic year 2020-21, who were seen as lost or confused. Students who could be helped by participating in the programme.

These students would receive hints and tips to get to know the different services of the university, the teaching staff or the subjects, with a point of view close to their own, the student mentor.

There was no public call for applications. First-year teaching staff from each of the EPSZ degrees were asked for help to select the participants. Individual contact was made with the students proposed by the first-year teaching staff.

Seven students participated, one per degree, except for the GAT, where none wanted to participate, and the GIISI, where two participated. Some of them were international students.

\section{DeVELOPMENT}

The period for the development of the pilot programme was short. It was challenging to carry out all phases of the mentoring relationship: construction, exchange, goal setting and final evaluation [10].

Moreover, although the people involved in the pilot are from the same Campus, they are not connected, so a common space for peer mentoring activities is necessary. To facilitate the work, an online space was developed for connecting all the participant involved in the peer mentoring. We use the virtual campus of the University of Salamanca, Studium. The online course incorporated guidance and training for each group of people involved.

The purpose of the pilot programme was to find out the needs of each group involved in the process, as well as to validate the training needs of students and teachers.

The actions planned are described in Table 2. There were two group meetings, one at the beginning and one at the end of the process. The group meetings were virtual due to the pandemic.

Table 2. Planning

\begin{tabular}{|c|cl|}
\hline Time Period & \multicolumn{1}{c|}{ Actions } \\
\hline $\begin{array}{c}1 \text { March to 10 } \\
\text { April }\end{array}$ & - & $\begin{array}{l}\text { Selection of mentor teachers, student mentors } \\
\text { and student mentees }\end{array}$ \\
- & $\begin{array}{l}\text { Development of resources for the training of } \\
\text { mentor teachers and student mentors }\end{array}$ \\
\hline 5 to 11 April & - & Preparation of questionnaires \\
\hline 16 April & - & $\begin{array}{l}\text { First meeting with mentored students and } \\
\text { presentation of the training and application of } \\
\text { pre-training questionnaires }\end{array}$ \\
\hline 1 to 8 June & - & $\begin{array}{l}\text { Preparation of evaluation/satisfaction } \\
\text { questionnaires of the programme }\end{array}$ \\
\hline 9 June & - & The second meeting, follow-up \\
\hline 10 to 20 June & - & $\begin{array}{l}\text { Completion of evaluation/satisfaction } \\
\text { questionnaires of the programme (teachers and } \\
\text { students) }\end{array}$ \\
\hline 21-30 June & - & Analysis of results \\
\hline
\end{tabular}

The mentored students and student mentors filled in a commitment and registration form. Questionnaires were applied before and after the experience to the three groups involved in order to detect the critical points of the proposal. We wanted to assess their previous expectations, feelings and level of satisfaction with the mentoring process.

\section{RESUlts}

Through the questionnaires, we receive the assessment and suggestions of those involved.

\section{A. Initial questionnaire}

The mentor students consider it essential, or very important, that new students know the academic guides and the different spaces (academic, university services, professors' offices, leisure). They think that participating will help them. It is worrying that in response to the question "The climate of the centre is inclusive" they indicate that there is room for improvement (Figure 2).

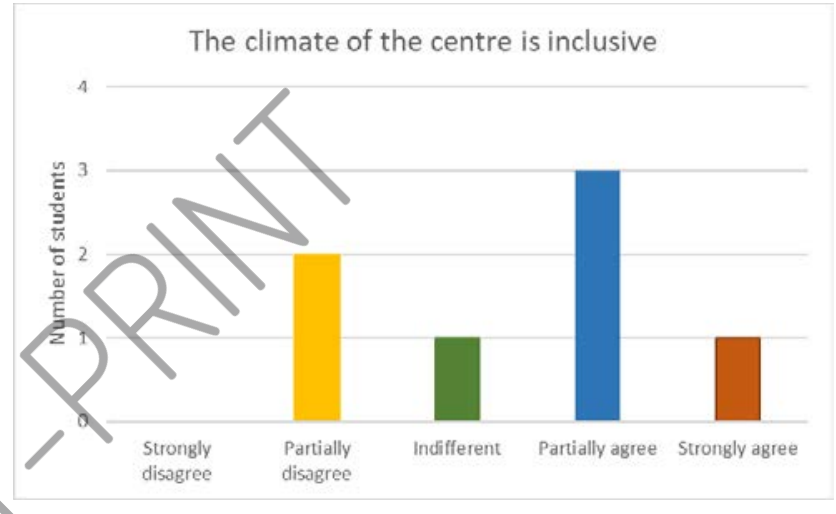

Fig. 2 Responses to "The climate of the centre is inclusive"

For the mentees, their integration into the school is very important. Despite being in the second semester, almost half of them hardly know the campus facilities. They interact with a small group of students, generally from their own class. Although we must not forget that we are in a pandemic.

None of them carries out activities with the sports service. They are unaware of the role of the guidance or assistance service for students.

When asked about the classroom climate, they are not optimistic either (Figure 3).

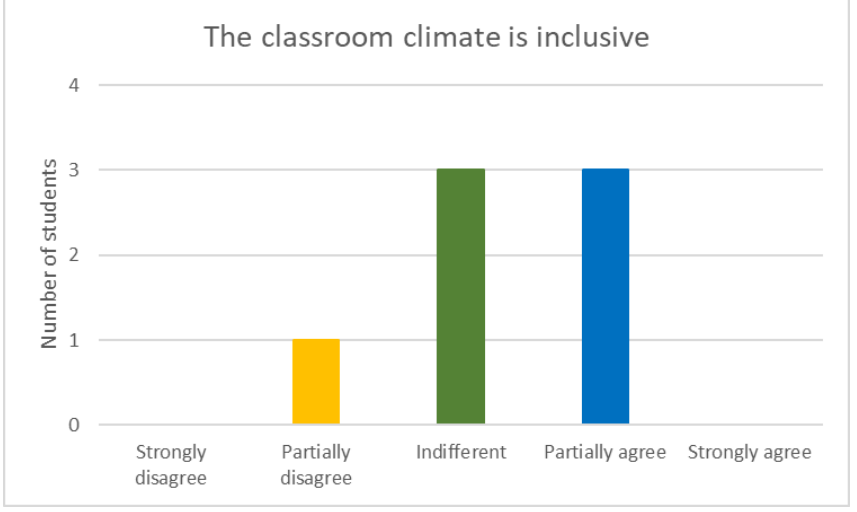

Fig. 3. Responses to "The classroom climate is inclusive" 


\section{B. Final questionnaire}

Both the participating teachers and the mentor trainees indicated that the training material developed was adequate. Among the suggestions of both groups was the holding of additional meetings internal to each group. To discuss ideas or homogenise actions.

The teachers were missing a guide or a protocol for action. They were particularly interested in guidelines so as not to interfere in the mentor-mentee relationship.

For all participants, the duration of the programme was insufficient and late in the development of the course. They consider attendance at the meetings to be relevant, although they would have preferred face-to-face meetings.

Concerning the time of interaction, it is diverse. From daily contacts to 30 minutes in the whole period, between mentors and mentees. Between mentors and mentees, the margin ranges from one hour to five minutes.

The perception they all have is that they have felt useful and supported.

All groups rated their participation in the programme positively. They indicate that their expectations have been met. They are satisfied with their participation in the programme. They would unanimously recommend participation in the programme.

\section{CONCLUSIONS}

Gender gap is a problem that affects the engineering sector. The number of students who enrol in engineering studies is lower than other tertiary studies. Moreover, these degrees have a high dropout rate. So, the problem is not only attracting more women into these studies but also reduce the dropout of those future women engineers. This work presents a pilot strategy to reduce the dropout of female engineer students through a peer mentoring mechanism which involves faculty mentors, peer mentors and female first-year students as mentees.

The pilot results provide feedback to improve the strategy and implement a full peer mentoring programme. The responses and suggestions received, as well as the organisation of the pilot programme, have helped us to detect the needs of students and teachers.

Highlight, it is necessary to start the programme at the beginning of the academic year in order to make it more useful for new students. Furthermore, as indicated by the participants, support meetings should be scheduled not only between levels but also within the same level.

However, with a small sample size, caution must be applied, the findings are an input for defining a mentoring programme with gender perspective, first for the EPSZ and after for other faculties or universities.

Setting up a mentoring programme can move EPSZ towards a more inclusive climate, a better integration of female students, which will help them successfully complete their studies.

\section{ACKNOWLEDGMENT}

We would like to thank all the people involved in the pilot programme for their participation, without their generous contribution, it would not have been possible. In particular, to the EPSZ student delegation, who never hesitated to contribute to the experience.

With the support of the Erasmus+ Programme of the European Union through Key Action 2 "Capacity-building in Higher Education". W-STEM project "Building the future of Latin America: engaging women into STEM" (Reference number 598923-EPP-1-2018-1-ES-EPPKA2-CBHE-JP). The contents of this publication do not reflect the official opinion of the European Union. The responsibility for the information and opinions expressed in the publication rests entirely with the authors.

\section{REFERENCES}

[1] F. Pérez, and J. Aldás. "U-Ranking, 7 a Edición. Indicadores Sintéticos de las Universidades Españolas". Valencia: Fundación BBVA - IVIE, 2020

[2] A. García-Holgado, A. Camacho Díaz, and F. J. García-Peñalvo, "Engaging women into STEM in Latin America: W-STEM project," in Proceedings of the 7th International Conference on Technological Ecosystems for Enhancing Multiculturality (TEEM 2019) (León, Spain, October 16-18, 2019), M. Á. Conde-González, F. J. Rodríguez Sedano, C. Fernández Llamas, and F. J. García-Peñalvo Eds., (ACM International Conference Proceeding Series (ICPS). New York, NY, USA: ACM, 2019, pp. 232-239.

[3] M. García García, M. Gaya López, and P. Velasco Quintana. "Mentoría entre iguales: alumnos que comparten experiencias y aprendizaje". Actas XVI Jornadas de Enseñanza Universitaria de la Informática (JENUI 2010), pp. 119-126. Santiago de Compostela: Universidade de Santiago de Compostela. Escola Técnica Superior d'Enxeñaría.

[4] N.L. Aguilar Aguilar and N. Manzano Soto. La mentoría en el nivel universitario: etapas para su implementación. Universidad y Sociedad, 10 (1), 255-262, 2018.

[5] A. Bernardo, R. Cerezo, J.C. Núñez, E. Tuero and M. Esteban. García. "Predicción del abandono universitario: variables explicativas y medidas de prevención”. Revista Fuentes, 16, 2015, pp. 63-84.

[6] A. Valverde, C. Ruíz, E. García Jiménez, and S. Romero. Innovación en la orientación universitaria: la mentoría como respuesta. Contextos Educativos, 6-7, 2004, pp. 87-112.

[7] J. Biggs. Calidad del aprendizaje universitaro. Madrid: Narcea, 2006.

[8] F. J. García-Peñalvo, M. J. Rodríguez-Conde, R. Therón, A. GarcíaHolgado, F. Martínez-Abad, and A. Benito-Santos, "Grupo GRIAL," IE Comunicaciones. Revista Iberoamericana de Informática Educativa, vol. 30, no. 33-48, 2019.

[9] F.J. García-Peñalvo. Women and STEM disciplines in Latin America. The W-STEM European Project. Journal of Information Technology Research, 12(4), 2019.

[10] N. Manzano, A. Martín Cuadrado, M. Sánchez García, A. Rísquez, M. Suárez Ortega. El rol del mentor en un proceso de mentoría universitaria. Educación XXI. 15.2, 2012, pp. 93-118

[11] P. Andrade-Abarca, Á. Salazar and M. Loaiza-Aguirre (2017). Buenas prácticas de innovación en la Educación Superior: la mentoría . La innovación docente como misión del profesorado. Actas del IV Congreso Internacional sobre Aprendizaje, Innovación y Competitividad (CINAIC 2017) p.p. 413-418. Zaragoza: Servicio de Publicaciones Universidad de Zaragoza.

[12] R. Casado Muñoz and M. Ruiz Franco, M.. Programa mentor: tutorías entre compañeros/as. 2009. Girona: Universitar de Girona. Institut de Ciències de l'Educació Josep Pallach. 